\title{
Analisis Pelayanan Obat-Obatan Dalam Kepuasan Konsumen Pada Apotek Syalom Amurang
}

\author{
Irene Sinta uli Silalahi \\ Johny R.E Tampi \\ Aneke Y. Punuindoong \\ Jurusan Ilmu Administrasi, Program Studi Administrasi Bisnis \\ Fakultas Ilmu Sosial dan Politik, Universitas Sam Ratulangi \\ email: irenesilalahi727@gmail.com
}

\begin{abstract}
This study aims to determine customer satisfaction with drug services at the Syalom Amurang Pharmacy. The focus of the research is, product quality, service quality, Emotional, Cost, and Price. The theory used in this study is the theory of Consumer Satisfaction by Lupyoadi. In this study using qualitative methods, data collection techniques are carried out through observation, interviews and documentation. The informants in this study were the Amurang City Community who had bought medicine at the Syalom Pharmacy. Location research at Syalom Amurang Pharmacy, with the basis used in law No. 25 of 2009 concerning the standard of public service, the standard of service that has been determined by the service unit, working to serve every citizen and resident to fulfill their rights is not the need for basic needs within the framework of service. Pharmacy units the importance of the service of medicines in community satisfaction can be measured by a predetermined standard, namely, service satisfaction for the services of the Syalom Pharmacy in Amurang in terms of service requirements, product quality, price, service quality, emotional, cost. From the 5 service standards there are results that state that they are not satisfied with the quality of service, product quality emotionally satisfied to eat a short service time, customer fees or rates according to and satisfied with service, price and cost, product quality, Syalom pharmacy Amurang field observation.
\end{abstract}

Keywords: Service, Consumer Satisfaction

\section{Pendahuluan}

Pelanggan adalah orang yang menyampaikan keinginannya kepada perusahaan. Tugas perusahaan adalah menanganinya supaya mendatangkan keuntungan. Dewasa ini, semakin banyak perusahaan yang mengakui pentingnya memuaskan dan mempertahankan pelanggan yang ada. Para pelanggan yang puas biasanya akan terkait dengan bertahannya pelanggan (Kolter, 2005).

Apotek merupakan suatu tempat tertentu dimana dilakukan usaha-usaha dalam bidang Farmasi, pekerjaan kefarmasian dan penyaluran obat kepada masyarakat. Kepuasan pasien dapat mempengaruhi minat untuk kembali ke apotek yang sama. Kepuasan merupakan pengalaman yang akan mengendap di 
dalam ingatan pasien sehingga mempengaruhi proses pengambilan keputusan pembelian ulang produk yang sama (Rini, dkk., 2006).

Kepuasan, merupakan salah satu tolak ukur penilaian setiap orang, yang dapat merasakan hasil dari kualitas pelayanan yang diberikan. Apakah sesuai dengan yang diharapkan atau sebaliknya, tidak sesuai dengan yang diharapkan. Setiap orang memiliki penilaian yang berbeda-beda tetapi itu tergantung standar pelayanan yang telah ditetapkan oleh organisasi. Pentingnya pelayanan dari setiap pegawai dalam hal ini, bisa memberikan pelayanan yang memuaskan kepada konsumen. Karena konsumen bisa dikatakan sebagai konsumen yang dilayani oleh para petugas pelayanan

Perilaku petugas kesehatan atau pemilik Apotek sikap mereka tidak dapat memberikan kepedulian penuh sesuai keinginan masyarakat sebagai pasien, perilaku pegawai atau petugas yang kurang ramah terhadap konsumen yang membuat konsumen terhadap pelayanan pegawai Apotek, dalam pelayanan administrasi menyangkut hal ketersediaan informasi, kejelasan informasi yang diberikan kepada konsumen yang kurang memadai, sehingga mempersulit konsumen untuk prosedur pelayanan.
Dilihat dari banyaknya Pembeli di Apotek Syalom Amurang, Kepuasan yang dirasakan dari segi persyaratan pelayanan, system mekanisme prosedur, biaya. Kualitas produk, kualitas pelayanan, biaya atau tarif lain tingkat emotional. Maupun jasa contoh kurangnya ketersediaan obatobatan tertentu, adanya keterlambatan dalam proses pelaksanaan adanya keterlambatan dalam proses pelayanan dari pihak petugas apotek sehingga menunggu lama. perbandingan antara kesannya terhadap kinerja (atau hasil) suatu produk dan harapan-harapannya. Hasilnya adalah kesetiaan pelanggan yang tinggi (Kolter,1997.

Berdasarkan observasi yang mengamati dan mencari informasi dari konsumen sekitar kondisi pelayanan Apotek yang dilaksanakan Apotek Syalom kota Amurang. Pelaksanaan Pelayanan yang diberikan Apotek Syalom kota Amurang, kepada masyarakat dan konsumen oleh petugas pegawai dan pemilik Apotek, masih ada ditemukan respon dari masyarakat baik konsumen puas dan kurang puas akan pelayanan yang diberikan.

Berdasarkan pengalaman ada beberapa petugas apotek yang tidak memberikan informasi obat kepada beberapa konsumen yang membeli obat di apotek. Berdasarkan uraian di atas 
sangatlah perlu dilakukan penelitian sejauh mana kepuasan konsumen terhadap pelayanan di apotek. Penelitian ini diharapkan dapat memberikan manfaat dan masukan bagi pihak apotek untuk meningkatkan mutu pelayanannya guna menunjang pelayanan kesehatan di apotek dan dapat melaksanakan peran dan fungsinya dengan baik untuk kepentingan dan kesejahteraan penderita.

\section{Kepuasan}

Kepuasan adalah perasaan senang atau kecewa seseorang yang berasal dari perbandingan antara kesannya terhadap kinerja (atau hasil) suatu produk dan harapan-harapannya. Hasilnya adalah kesetiaan pelanggan yang tinggi (Kolter,1997).

\section{Kualitas pelayanan}

Kualitas pelayanan menurut Thoha (1995: 181) adalah ukuran penilaian yang menyeluruh dari berbagai perbandingan antara pelayanan yang diharapkan pelanggan dengan kinerja pelayanan aktual yang diterima pelanggan

\section{Kepuasan Konsumen}

Kepuasan Konsumen Menurut Lukman (2000:119), Menyatakan bahwa kepuasan sebagaimana tingkat persamaan seseorang setelah membandingkan kinerja (hasil) yang dirasakan dengan harapannya. Sejalan dengan pemikiran, Gibson dkk (1987),
Wexley dan Yulk (1998), dijelaskan bahwa kepuasan pada hakekatnya berkaitan dengan faktor kebutuhan seseorang terpenuhi maka orang tersebut merasa puas, demikian pula sebaliknya.

\section{Indeks Kepuasan Konsumen}

Indeks kepuasan konsumen adalah data dan informasi tentang tingkat kepuasan konsumen yang diperoleh dari hasil pengukuran secara kuantitatif dan kualitatif atas pendapat konsumen dalaam memperoleh pelayanan dari aparatur penyelenggara pelayanan publik dengan membandingkan antara harapan dan kebutuhannya (Peraturan Menteri Pendayagunaan Aparatur Negara Nomor 25 Tahun 2004).

\section{Metode Penelitian}

Metode penelitian yang dipakai dengan pendekatan analisis deskriptif kualitatif. Menurut Meleong (2013) bahwa penelitian kualitatif adalah penelitian yang bermaksud memahami fenomena tentang apa yang dinilai oleh subjek penelitian misalnya perilaku, persepsi, motivasi tindakan dll. Secara holistik dan dengan cara deskriptif dalam bentuk kata-kata dan bahasa, pada suatu konteks khusus yang alamiah dan dengan memanfaatkan berbagai metode alamiah.

Penelitian ini dilaksanakan di Apotek Syalom Amurang. Adapun fokus Penelitian adalah kepuasan konsumen di 
Apotek Syalom Amurang dalam beberapa aspek yang dilihat dari masalah dilapangan, dan yang menjadi pembahasannya :

a. Kualitas produk, yaitu pelanggan akan merasa puas bila hasil mereka menunjukkan bahwa produk yang mereka gunakan berkualitas.

b. Kualitas pelayanan atau jasa, yaitu pelanggan akan merasa puas bila mereka mendapatkan pelayanan yang baik atau sesuai dengan yang diharapkan.

c. Emosi, yaitu pelanggan akan merasa bangga dan mendapatkan keyakinan bahwa orang lain akan kagum terhadap dia bila menggunakan produk dengan merek tertentu yang cenderung mempunyai tingkat kepuasan yang lebih tinggi. Kepuasan yang diperoleh bukan karena kualitas dari produk tetapi sosial atau self esteem yang membuat pelanggan merasa puas terhadap merek tertentu.

d. Harga, yaitu produk yang mempunyai kualitas yang sama tetapi menetapkan harga yang relatif murah akan memberikan nilai yang lebih tinggi kepada pelanggan.

\section{Informan Penelitian}

Informan penelitian ini sebanyak 8 orang diantaranya pemilik dan konsumen.

Sumber data utama dalam penelitian kualitatif adalah kata-kata dan tindakan, selebihnya ialah data tambahan seperti dokumen dan lain-lain. Penelitian kualitatif menggunakan metode kualitatif yaitu pengamatan, wawancara atau penelaahan dokumen (Meleong, 2006). Bedasarkan pendapat tersebut maka instrumen utama dalam penelitian ini ialah peneliti sendiri, sedangkan teknik pengumpulan data yang digunakan ialah sebagai berikut :

Observasi diartikan sebagai pengamatan dan pencatatan secara sistematik terhadap gejala yang nampak pada objek penelitian dalam penelitian ini observasi yang dilakukan oleh penulis adalah observasi berperan pasif dimana peneliti kehadiranya dalam melakukan observasi tidak diketahui oleh subjek yang diamati.Peneliti hanya mendatangi lokasi, tetapi sama sekali tidak berperan sebagai apapun selain sebagai pengamat pasif. Sutopo (2002: 66)

Yang digunakan dalam penelitian ini adalah jenis wawancara mendalam. Menurut Sutopo(2002:58) wawancara mendalam merupakan yang tidak stuktur, karena peneliti merasa perlu melakukan wawancara mendalam untuk mencari informasi yang jelas dan akurat .Peneliti melakukan wawancara secara mendalam kepada informan yaitu konsumen, serta mencatat adian serta informasi dari informan yang kemudian dijadikan sebagai bahan penulisan laporan hasil penelitian. Informan yaitu orang yang memiliki pengetahuan dan pengalaman sebagai partisipan untuk menggali informasi 
.Informan yang diwawancari diantaranya konsumen yang terdiri dari beberapa ruang lingkup kerja Apotek Syalom.

$$
\text { Menurut Sutopo (2002 : }
$$

dokumentasi adalah sumber data yang memliki peran yang penting dalam penelitian kualitatif . Dokumen bisa memiliki beragam bentuk dari yang tertulis sederhana sampai pada yang lebih lengkap seperti catatan, transkip, buku, surat kabar dan sebagainya.

Analisis data kualitatif menurut Bogman dan Biklen dalam ( Moleong, 2006) adalah upaya yang dilakukan dengan jalan bekerja dengan data, mengorganisasikan data, memilahmilahnya menjadi satuan yang dapat dikelola, mensistensikanya, mencari dan menemukan apa yang penting dari apa yang diperlajari dan memutuskan apa yang dapat di ceritakan kepada orang lain.

\section{Hasil Dan Pembahasan}

Hasil Penelitian mengenai Analisis pelayanan obat-obatan dalam kepuasan konsumen pada Apotek Syalom dari delapan informan yang diwawancarai, masyarakat mengatakan puas, cukup puas dan kurang puas dari apa yang mereka rasakan dari pelayanan pihak apotek dan petugas karyawan Apotek Syalom. Beberapa fokus penelitian yaitu kualitas produk, Harga, Kualitas pelayanan, Emotional, Biaya, sarana dan prasarana dan fasilitas, tempat pengaduan keluhan dan saran, dan standar pelayanan.

Sesuai dengan teori yang mengatakan secara umum menurut Kolter (2005)

Adalah perasaan seseorang yang atau kecewa seseorang yang muncul setelah membandingkan antara kinerja produk atau hasil yang diinginkan. Jika kinerja memenuhi harapan, maka pelanggan akan puas. Jika kinerja melebihi harapan, maka pelanggan akan merasa amat puas.

Produk maupun jasa, contoh ketersediaan Obat-obatan tertentu untuk semua pihak konsumen sebagian mengatakan puas dan kurang puas dengan produk yang tersedia, seperti untuk jenis sakit kronis kadang belum memadai sehingga konsumen merasa kesulitan, dikarenakan juga kadang obat obatan terlalu mahal, ketersediaan obat-obatan belum terlalu banyak dan jenisnya.

Dari pelayanan yang diberikan oleh pegawai dan petugas Apotek kepada masyarakat yang menimbulkan rasa senang atau sebaliknya, senang dilihat dari respon yang mengatakan puas akan sesuatu yang telah dilakukan, kurang puas apabila tidak senang.

Yang pertama dari segi kualitas produk konsumen mengatakan puas akan pelayanan yang diberikan tidak dipersulit, kedua harga cukup puas bisa diikuti dengan mudah dan terjangkau oleh konsumen, 
ketiga puas akan kualitas pelayanan dan ada juga kurang puas, keterampilan juga bisa dipahami mereka bisa menyampaikan dengan jelas dan memberikan informasi yang dibutuhkan konsumen merasa puas, keempat Emotional factor, yang singkat beberapa mengatakan beberapa puas ada juga yang mengatakan kurang puas seperti yang dikatakan Saudari N.S 24 Tahun "Tentang Emotional factor yang diberikan Apotek Syalom saya merasa kurang puas misalnya bagian pelayanan dalam penjelasan resep obat kepada saya ,saat mereka memberikan penjelasan secara cepat itu membuat saya kurang mengerti dan susah saya pahami dari pihak Apotek dan petugas karyawan.” Ibu A.C 47 Tahun mengatakan puas "Ya saya merasa puas dengan sikap emotional karyawan dapat melayani dengan baik tidak terlalu lama cepat diproses oleh petugas dan pegawai Apotek"

Dari dua orang yang merasakan hal yang berbeda karena sikap pelayanan dari pihak apotek kurang memuaskan ketika memberikan penjelasan secara terperinci, sehingga membuat konsumen susah mengerti dan memahami.

Dalam hal ini bisa disimpulkan bahwa kualitas pelayanan pada apotek Syalom masih kurang dalam penjelasan mengenai cara pakai obat dan fungsi obat tersebut. Mungkin salah satu faktor nya yaitu apotek yang masih baru dan belum di kenal banyak orang yang oleh karena nya pekerja masih asal-asalan dalam melayani konsumen. Jika pelayanan mereka jauh lebih baik mungkin apotek tersebut bisa cepat diketahui banyak orang karena tinggi rendahnya kualitas penjualan ditentukan oleh seberapa baik pelayanan tersebut.

Maka dari masukan dan saran delapan informan mengatakan pentingnya adanya tempat pengaduan atau kotak saran diketahui oleh konsumen dan masyarakat untuk melihat seberapa banyak konsumen dapat merasakan baik atau kurang baik dari pelayanan yang diberikan agar dapat menambahkan atau memperbaiki hal ha pelayanan tersebut, sehingga konsumen merasa puas dan merasa dilayani dengan baik.

Maka dari itu Apotek Syalom harus lebih juga meningkatkan kualitas jenis obat-obatan dan terutama dalam pelayanan yang diberikan kepada para konsumen. Diusul keluhan dari pembeli di apotek yang mengatakan dari salah satu konsumen yang membeli obat di apotek masih bingung akan pelayanan pihak dari apotek, ketika pihak petugas atau pemilik apotek kurang tanggap atau terlalu cepat dalam memberikan setiap penjelasan mengenai resep atau jenis obat-obatan untuk pemakaiannya. Pengaduan keluhan dan saran informan mengatakan tidak mengetahui hal itu dan tidak tau bahwa adanya tempat pengeluhan dan saran kepada Apotek, pentingnya tempat 
pengaduan keluhan dan saran diketahui oleh masyarakat untuk melihat seberapa masyarakat baik konsumen dapat merasakan baik atau kurang baik pelayanan yang diberikan agar dapat menambahkan atau memperbaiki hal-hal apa saja yang perlu di Puskesmas, terutama dalam pelayanan yang diberikan.

\section{Daftar Pustaka}

Dendawijaya, Lukman. 2000. Manajemen Perbankan Ghalia Indonesia: Jakarta.

Gibson, James, L., et al. (1987) Organisasi dan Manajemen Perbankan Ghalia Indonesia: Jakarta. Proses Binarupa Aksara.

Kolter, Philip, 2002, Manajemen Pemasaran. Jilid 1, Edisi Milenium, Jakarta, Prehallindo.

Kolter, Philip. 1997. Manajemen Pemasaran Analisis Perencanaan, Implementasi dan Pengendalian, Salemba Empat. Jakarta

Kolter, Philip, 2005, Manajemen Pemasaran, Jilid 1 dan II, PT. Indeks, Jakarta

Meleong, J, Lexy. 2006. Metodologi Penelitian Kualitatif Bandung: PT. Remaja Rosdakarya

Sutopo. H.B. 2002 Pengantar Penelitian Kualitatif. Surakarta: Universitas Sebelas

Tjiptono, Fandy. 2002. Strategi Pemasaran Yogyakarta: Penerbit Andi Ibrahim $2000: 1$

Tjiptono, Fandy, 2007. Metode Riset Bisnis Edisi Pertama. Jakarta: PT. Gramedia Pustaka Utama.
Wexley, K, N, dan Yulk, L,A 1988. Organizational Behavior dan Personel Psychology. Boston. Richard D, Irwin, INC. 